\title{
Effects of cycloheximide on the uterine refractory state induced by 'nidatory' oestrogen in rats
}

\author{
F. Leroy, J. Van Hoeck and B. Lejeune \\ Human Reproduction Research Unit, St-Pierre Hospital, Free University of Brussels, Brussels, \\ Belgium
}

\begin{abstract}
Summary. After priming with oestradiol, ovariectomized rats were given 6 days of progesterone treatment in which two doses of $50 \mathrm{ng}$ oestradiol were given on Days 3 and 6. This basic treatment allows the oestradiol-induced (1st injection) disappearance of uterine sensitivity to decidual stimuli to occur. Cycloheximide could not mimic oestrogen action in the production of the uterine refractory state. However, a high dose $(500 \mu \mathrm{g}$ per animal) of this inhibitor given with the first injection of oestradiol allowed the uterus to remain in a neutral state and to respond to decidual induction after the second dose of oestradiol. By delaying the injection of cycloheximide after the first oestrogen treatment, protein synthesis requisite to the occurrence of uterine refractoriness would not take place within $12 \mathrm{~h}$ after the 'nidatory' oestrogen injection.
\end{abstract}

\section{Introduction}

In rats and mice, sensitization of the uterus to implantation requires that small amounts of oestrogen should act in addition to the permissive role carried out by progesterone secretion (see Finn, 1977). Uterine receptivity, however, is short-lived and evolves after a few hours into a refractory state in which the uterus is no longer adapted to the implantation reaction. In the progesterone-dominated uterus, small amounts of oestrogen thus induce a sequence of events resulting in a state of insensitivity which may therefore be taken as a criterion for 'nidatory' oestrogen action (see Psychoyos, 1974).

Previous work showed that actinomycin D could neither elicit nor prevent the occurrence of the uterine refractory state (Leroy, Van Hoeck \& Bogaert, 1976). Together with other data from the literature (Finn \& Martin, 1974), this observation suggested that at least some of the effects of 'nidatory' oestrogen are not mediated through genetic transcription. It has been also repeatedly stressed, for the uterus (Gorski \& Nelson, 1965; Mueller, 1965; Notides \& Gorski, 1966; Hamilton, 1971) as well as for other target systems (Tomkins et al., 1969; Smith \& Ecker, 1970; Brachet, 1972), that steroid hormones might directly control RNA translation. A preliminary report of examination of the possibility that 'nidatory' oestrogen would regulate some of the endometrial cell functions by directly influencing protein synthesis concluded that such was not the case (Leroy, Bogaert \& Van Hoeck, 1975). The present paper studied the effect of high doses of cycloheximide on the occurrence of the oestrogen-induced refractory state of the uterus.

\section{Materials and Methods}

Wistar rats, weighing from 130 to $150 \mathrm{~g}$, were anaesthetized with tribromoethyl alcohol (Avertin: Winthrop) and ovariectomized through dorsal incisions. After 6 days they were submitted to a priming treatment consisting of a daily injection of $500 \mathrm{ng}$ oestradiol-17 $\beta$ for 2 days, followed by 2 days of rest. Groups of rats were then given a hormonal regimen of a daily dose of 
$3 \mathrm{mg}$ progesterone for 6 days, on which an injection of $50 \mathrm{ng}$ oestradiol-17 $\beta$ was superimposed either on Day 3 only, or on Days 3 and 6 (Day $1=$ day of first injection).

In Exp. 1 (Table 1) groups of animals were treated with 60,200 or $500 \mu \mathrm{g}$ cycloheximide (Sigma, St Louis) on Day 3, either alone (Groups IIIa, b and c) or $2 \mathrm{~h}$ before the first injection of $50 \mathrm{ng}$ oestradiol-17 $\beta$. (Groups IVa, b and c.)

In Exp. 2 (Table 2) all animals were given $50 \mathrm{ng}$ oestradiol- $17 \beta$ on Days 3 and 6, as well as $450 \mu \mathrm{g}$ cycloheximide on Day 3. Different experimental groups corresponded to increasing delay $(0-30 \mathrm{~h})$ before administration of the inhibitor, after the first dose of oestradiol.

Deciduomata were induced in all rats on the morning of Day 7, i.e. $12 \mathrm{~h}$ after injection of oestradiol given on Day 6. This was achieved through instilling $30 \mu \mathrm{l}$ arachis oil into one horn while the other was scratched antimesometrially along the lumen. Between deciduomal induction and killing, which took place 5 days later, all animals received a daily injection of 2 mg progesterone plus $200 \mathrm{ng}$ oestradiol- $17 \beta$ in order to allow proper development of the decidual reaction (Yochim \& De Feo, 1962).

Hormones were injected subcutaneously in 50 or $100 \mu \mathrm{l}$ arachis oil and cycloheximide, dissolved in $0.5 \mathrm{ml} 0.9 \%(\mathrm{w} / \mathrm{v}) \mathrm{NaCl}$, was given intraperitoneally. After recording of macroscopic deciduomal responses, the excised uterine horns were weighed separately for each animal.

\section{Results}

\section{Experiment 1}

As shown in Table 1, the control animals having received only one dose of oestradiol on Day 6 of progesterone treatment (Group I) developed a fairly large decidual reaction in both horns, but only 1 rat responded to induction when oestradiol had been given on Days 3 and 6 (Group II).

Table 1. Effect of different doses of cycloheximide on the refractory state induced in the uterus by oestrogen in rats

\begin{tabular}{|c|c|c|c|c|c|c|c|c|c|c|}
\hline \multirow[b]{2}{*}{ Group } & \multicolumn{7}{|c|}{ Daily treatment before decidual induction } & \multirow{2}{*}{$\begin{array}{l}\text { No. of rats } \\
\text { responding/ } \\
\text { no. treated }\end{array}$} & \multicolumn{2}{|c|}{$\begin{array}{l}\text { Mean } \pm \text { s.e.m. weight }(\mathrm{mg}) \\
\text { of horns treated by: }\end{array}$} \\
\hline & 1 & 2 & 3 & 4 & 5 & 6 & 7 & & Oil & Scratching \\
\hline I & $\mathbf{P}$ & $\mathbf{P}$ & $\mathbf{P}$ & $\mathbf{P}$ & $\mathbf{P}$ & $P+e$ & Ind & $8 / 8$ & $506 \pm 258$ & $1106 \pm 336$ \\
\hline II & $\mathbf{P}$ & $\mathbf{P}$ & $P+e$ & $\mathbf{P}$ & $\mathbf{P}$ & $P+e$ & Ind & $1 / 7$ & $126 \pm 23$ & $180 \pm 171$ \\
\hline IIIa & $\mathbf{P}$ & $\mathbf{P}$ & $P+C h x(60 \mu g)$ & $\mathbf{P}$ & $\mathbf{P}$ & $\mathrm{P}+\mathrm{e}$ & Ind & $8 / 8$ & $713 \pm 134$ & $1368 \pm 197$ \\
\hline IIIb & $\mathbf{P}$ & $\mathbf{P}$ & $\mathrm{P}+\mathrm{Chx}(200 \mu \mathrm{g})$ & $\mathbf{P}$ & $\mathbf{P}$ & $P+e$ & Ind & $8 / 8$ & $1028 \pm 205$ & $1465 \pm 316$ \\
\hline IIIc & $\mathbf{P}$ & $\mathbf{P}$ & $P+\operatorname{Chx}(500 \mu \mathrm{g})$ & $\mathbf{P}$ & $\mathbf{P}$ & $\mathbf{P}+\mathrm{e}$ & Ind & $7 / 7$ & $539 \pm 97$ & $1024 \pm 214$ \\
\hline IVa & $\mathbf{P}$ & $\mathbf{P}$ & $P+C h x(60 \mu g)+e$ & $\mathbf{P}$ & $\mathrm{P}$ & $P+e$ & Ind & $0 / 8$ & $118 \pm 20$ & $113 \pm 18$ \\
\hline $\mathrm{IVb}$ & $\mathbf{P}$ & $\mathbf{P}$ & $\mathrm{P}+\mathrm{Chx}(200 \mu \mathrm{g})+\mathrm{e}$ & $\mathbf{P}$ & $\mathrm{P}$ & $P+e$ & Ind & $2 / 8$ & $179 \pm 191$ & $187 \pm 198$ \\
\hline IVc & $\mathrm{P}$ & P & $\mathrm{P}+\mathrm{Chx}(500 \mu \mathrm{g})+\mathrm{e}$ & $\mathrm{P}$ & $\mathrm{P}$ & $\mathrm{P}+\mathrm{e}$ & Ind & $8 / 8$ & $401 \pm 95$ & $755 \pm 88$ \\
\hline
\end{tabular}

All animals were given $500 \mathrm{ng}$ oestradiol $-17 \beta$ on Days -3 and -2 and no treatment on Days -1 and $0 . P=3 \mathrm{mg}$ progesterone; $\mathrm{e}=50 \mathrm{ng}$ oestradiol-17 $\beta$; Chx: cycloheximide. After decidual induction (Ind.) all animals received daily $2 \mathrm{mg}$ progesterone $+200 \mathrm{ng}$ oestradiol $-17 \beta$ for 5 days, after which they were killed. When groups with $100 \%$ decidualized uteri were statistically compared in terms of animal numbers with those showing none or only one positive response, the differences were significant at $P<0.013$ (factorial method for low numbers). The same group comparisons tested for uterine horn weights were significant at $P<0.005$ (Student's $t$-test).

Cycloheximide given on Day 3 instead of the first sensitizing oestradiol injection did not prevent decidualization, whatever the dose used (Groups IIIa, b and c). When the inhibitor was administered $2 \mathrm{~h}$ before oestradiol on Day 3 the results varied according to the dose administered, only the animals receiving $500 \mu \mathrm{g}$ responding totally (Group IVc). 


\section{Experiment 2}

As shown in Table 2, a $100 \%$ induction rate and a maximal deciduomal reaction was obtained when the inhibitor was injected as late as $12 \mathrm{~h}$ after the oestrogen. Beyond that, however, the weight of the scratched and oil-treated uterine horns was significantly lower, while decidualization was no longer found in all animals. At $30 \mathrm{~h}$ only 1 animal showed a small decidual response.

Table 2. Effect of $450 \mu \mathrm{g}$ cycloheximide on the uterine refractory state induced by oestrogen in rats

\begin{tabular}{cccccc}
\hline $\begin{array}{c}\text { Time between } \\
\text { cycloheximide } \\
\text { and oestradiol } \\
\text { on Day } 3(\mathrm{~h})\end{array}$ & \multicolumn{2}{c}{$\begin{array}{c}\text { No. of rats } \\
\text { responding/no. treated }\end{array}$} & & \multicolumn{2}{c}{ Mean \pm s.e.m. wt of uterine horns (mg) } \\
\cline { 5 - 6 } \cline { 5 - 6 } \cline { 5 - 6 } & Oil & Scratching & & Oil & Scratching \\
\hline 0 & $7 / 8$ & $7 / 8$ & & $550 \pm 116$ & $1092 \pm 177$ \\
+1 & $8 / 8$ & $8 / 8$ & & $582 \pm 33$ & $1175 \pm 44$ \\
+4 & $7 / 7$ & $7 / 7$ & & $484 \pm 54$ & $1226 \pm 65$ \\
+8 & $5 / 5$ & $5 / 5$ & & $631 \pm 162$ & $908 \pm 136$ \\
+12 & $7 / 7$ & $7 / 7$ & & $672 \pm 114^{*}$ & $1285 \pm 62 \dagger$ \\
+16 & $6 / 8$ & $5 / 8$ & & $272 \pm 89^{*}$ & $457 \pm 131^{\dagger} \dagger$ \\
+20 & $1 / 5$ & $3 / 5$ & & $135 \pm 17$ & $348 \pm 128$ \\
+24 & $3 / 9$ & $7 / 9$ & & $335 \pm 90$ & $596 \pm 154$ \\
+30 & $1 / 7$ & $1 / 7$ & & $134 \pm 26$ & $266 \pm 161$ \\
\hline
\end{tabular}

* Significantly different, $P<0.02$ (Student's $t$ test).

$\dagger$ Significantly different, $P<0.001$ (Student's $t$ test).

\section{Discussion}

The uterine refractory state has been demonstrated by various experimental procedures (see Psychoyos, 1974; Finn, 1977). The method employed in the present work consists in delaying the application of a decidualizing stimulus after the injection of a small dose of oestrogen to ovariectomized animals treated chronically with progesterone. If stimulation of the uterine horns is applied later than $24 \mathrm{~h}$ after the oestrogen, decidualization fails to occur (Meyers, 1970). Our results (Group II, Table 1) confirm that even if a second dose of oestrogen is given later on, the uterus cannot be forced again into receptivity and will remain insensitive as long as adequate amounts of progesterone are provided.

Cycloheximide has been widely used as a specific inhibitor of ribosome-dependent polypeptide synthesis in eukaryotes (see Sisler \& Siegel, 1967). This drug is able to prevent oestrogen-induced protein synthesis in the rat uterus (Gorski \& Notides, 1969; Jensen, Numata, Brecher \& De Sombre, 1971). The present results indicate that cycloheximide is unable to mimic the desensitizing effect of oestradiol (Groups IIIa, b and c, Table 1). However, when this inhibitor was given shortly before the first dose of oestradiol it was capable of abolishing the oestrogenic effect, provided that the amount given was $500 \mu \mathrm{g}$ per rat. Under such conditions this drug allowed the uterus to remain in the neutral state and to respond positively to further oestrogenization and deciduomal induction (Group IVc, Table 1). Our results therefore suggest that the occurrence of the uterine refractory state, which follows uterine receptivity as an ultimate consequence of 'nidatory' oestrogen action, somehow requires protein synthesis.

Pertinent to this discussion are the data indicating that several effects of 'nidatory' oestrogen can not be mediated through stimulation of DNA transcription. Finn \& Martin (1972) reported that actinomycin $\mathrm{D}$ given before a small dose of oestradiol did not prevent the Pontamine blue reaction or the stromal oedema which can be observed in the progestational uterus in response to 
an oil decidual stimulus. It was also found that under such conditions the antibiotic could only delay decidualization without being able to abolish it. The occurrence and transmission of the oestrogen-dependent information allowing the decidual response are thus not precluded by this drug. Moreover, subsequent studies (Finn \& Bredl, 1973; Pollard, Bredl \& Finn, 1973) showed that actinomycin $\mathrm{D}$ did not prevent the oestrogen-induced attachment of blastocysts transferred from mice in delayed implantation, or the "second stage" of uterine closure which also depends on 'nidatory' oestrogen (Pollard \& Finn, 1972). Far from having an inhibitory effect, actinomycin D was found capable of inducing attachment of delayed blastocysts (Finn, 1974; Finn \& Downie, 1975; Aitken, 1977). Our own results, using an experimental programme similar to that employed in the present work, showed that even high doses of actinomycin D could not prevent the uterine refractory state (Leroy et al., 1975).

By adding the above mentioned evidence to the inhibitory effect of cycloheximide which we observed, we suggest that 'nidatory' oestrogen at least partly acts by allowing translation of stable m-RNA (or class of RNAs). A general model for the onset of ovum implantation in which such an effect is accounted for has been presented (Leroy, 1978).

With an oil stimulus deciduomal induction is necessarily mediated through the uterine epithelium, but it has been suggested that scratching by-passes this initial step and acts directly on the stroma (Finn \& Martin, 1974). Another interpretation, however, is that uterine trauma can elicit decidualization only if it also damages the epithelium and that the release of some epithelial message is therefore requisite (Psychoyos, 1974; Thibault, 1978). In our experiments the results obtained by oil injection and scratching were similar in all groups, although the latter procedure induced larger deciduomata than oil. It is therefore unclear whether the effect of cycloheximide on the refractory state is attributable to its action on epithelial or on stromal cells. Small amounts of oestrogen acting on the progesterone-treated uterus have been found to increase protein synthesis in both endometrial tissues (Smith, Martin, King \& Vértes, 1970; Pollard \& Martin, 1975).

The time-related effect of cycloheximide that we observed in Exp. 2 indicates that the protein synthesis which is involved in the mechanism of uterine refractoriness takes place between 12 and $16 \mathrm{~h}$ after oestrogen administration. Surani (1977) has shown that for the same duration of 'nidatory' oestrogen action there is a peak production of newly synthesized proteins of high molecular weight in the rat uterus. Although these observations do not allow a clear distinction between uterine protein secretion and synthesis they may nevertheless bear relevance to the occurrence of uterine refractoriness.

F.L. is "Chercheur Qualifie" at the Belgian F.N.R.S. This work was supported by a grant from the Belgian F.R.S.M.

\section{References}

Aitken, R.J. (1977) The influence of actinomycin D on the protein composition of mouse uterine flushings. $J$. Reprod. Fert. 50, 193-195.

Brachet, J. (1972) In General Discussion. Acta endocr., Copenh., Suppl. 168, 446-447.

Finn, C.A. (1974) The induction of implantation in mice by actinomycin D. J. Endocr. 60, 199-200.

Finn, C.A. (1977) The implantation reaction. In Cellular Biology of the Uterus, 2nd edn, pp. 246-308. Ed. R. E. Wynn. Plenum Press, New York.

Finn, C.A. \& Bredl, J.C.S. (1973) Studies on the development of the implantation reaction in the mouse uterus: influence of actinomycin D. J. Reprod. Fert. 34, 247-253.

Finn, C.A. \& Downie, J.M. (1975) Changes in the endo- metrium of mice after the induction of implantation by actinomycin D. J. Endocr. 65, 259-264.

Finn, C.A. \& Martin, L. (1972) Temporary interruption of the morphogenesis of deciduomata in the mouse uterus by actinomycin D. J. Reprod. Fert. 31, 353-358.

Finn, C.A. \& Martin, L. (1974) The control of implantation. J. Reprod. Fert. 39, 195-206.

Gorski, J. \& Nelson, N.J. (1965) Ribonucleic acid synthesis in rat uterus and its early response to oestrogen. Archs Biochem. Biophys. 110, 284-290.

Gorski, J. \& Notides, A. (1969) Estrogen control of uterine growth. Synthesis of specific uterine proteins. In Biochemistry of Cell Division, pp. 57-76. Ed. R. Baserga. C. C. Thomas, Springfield, Illinois.

Hamilton, T.H. (1971) Steroid hormones, ribonucleic 
acid synthesis and transport, and the regulation of cytoplasmic translation. In The Biochemistry of Steroid Hormone Action, pp. 49-84. Ed. R. M. S. Smellie. Academic Press, London.

Jensen, E.V., Numata, M., Brecher, P.I. \& DeSombre, E.R. (1971) Hormone-receptor interaction as a guide to biochemical mechanism. In The Biochemistry of Steroid Hormone Action, pp. 133-159. Ed. R. M. S. Smellie. Academic Press, London.

Leroy, F. (1978) Aspects moléculaires de la nidation. In L'Implantation de l'Oeuf, pp. 81-92. Eds F. du Mesnil du Buisson, A. Psychoyos \& K. Thomas. Masson, Paris.

Leroy, F., Bogaert, C. \& Van Hoeck, J. (1975) Inactivité de la cycloheximide sur certains effets des steroïdes ovariens responsables du conditionnement de l'utérus à la nidation. C. r. hebd. Séanc. Acad. Sci., Paris D 281, 2005-2007.

Leroy, F., Van Hoeck, J. \& Bogaert, C. (1976) Inability of actinomycin $D$ to act upon the uterine refractory state resulting from nidatory oestrogen action in rats. J. Endocr. 68, 137-140.

Meyers, K. (1970) Hormonal requirements for the maintenance of oestradiol-induced inhibition of uterine sensitivity in the ovariectomized rat. $J$. Endocr. 46, 341-345.

Muelter, G.L. (1965) The role of RNA and protein synthesis in oestrogen action. In Mechanisms of Hormone Action, pp. 228-245. Ed. P. Karlson. Academic Press, London.

Notides, A. \& Gorski, J. (1966) Estrogen-induced synthesis of specific uterine protein. Proc. natn. Acad. Sci. U.S.A. 56, 230-235.

Pollard, R.M. \& Finn, C.A. (1972) Ultrastructure of the uterine epithelium during the hormonal induction of sensitivity and insensitivity to a decidual stimulus in the mouse. J. Endocr. 55, 293-298.
Pollard, J.W. \& Martin, L. (1975) Cytoplasmic and nuclear non-histone proteins and mouse uterine cell proliferation. Molec. cell. Endocr. 2, 183-191.

Pollard, R.M., Bredl, J.C. \& Finn, C.A. (1973) Ultrastructure of the effect of actinomycin $D$ on the attachment reaction of implantation in mice. $J$. Reprod. Fert. 33, 343-345.

Psychoyos, A. (1974) Hormonal control of ovoimplantation. Vitams Horm. 32, 201-256.

Sisler, H.D. \& Siegel, M.R. (1967) Cycloheximide and other glutarimide antibiotics. In Antibiotics, pp. 283-296. Eds D. Gottlieb \& P. D. Shaw. Springer, Berlin.

Smith, L.D. \& Ecker, R.R. (1970) Regulatory processes in the maturation and early cleavage of Amphibian eggs. Curr. Topics Devl Biol. 5, 1-38.

Smith, J.A., Martin, L., King, R.J.B. \& Vértes, M. (1970) Effects of oestradiol-17\% and progesterone on total and nuclear-protein synthesis in epithelial and stromal tissues of the mouse uterus, and of progesterone on the ability of these tissues to bind oestradiol-17 $\beta$. Biochem. J. 119, 773-784.

Surani, M.A.H. (1977) Radiolabelled rat uterine luminal proteins and their regulation by oestradiol and progesterone. J. Reprod. Fert. 50, 289-296.

Thibault, C. (1978) L'implantation: sa programmation. In L'Implantation de l'Oeuf, pp. 1-19. Eds F. du Mesnil du Buisson, A. Psychoyos and K. Thomas. Masson, Paris.

Tomkins, G.M., Gelehrter, T.D., Granner, D., Martin, D., Jr, Samuels, H.J. \& Thompson, B. (1969) Control of specific gene expression in higher organisms. Science, N.Y. 166, 1474-1480.

Yochim, J.M. \& De Feo, V.J. (1962) Control of decidual growth in the rat by steroid hormones of the ovary. Endocrinology 71, 134-142.

Received 26 August 1978 